\title{
Effect of Immersion in Water on Linear Expansion and Strength of Three Base/liner Materials
}

\author{
Masao IRIE and Hiroyuki NAKAI \\ Department of Dental Materials, Okayama University Dental School, \\ 2-5-1, Shikata-cho, Okayama 700, Japan
}

Received January 5, 1995/Accepted April 21, 1995

\begin{abstract}
The purpose of this study was to characterize three base/liner materials in the initial stage of setting, $i$. $e$., dual-cured (light-activated glass ionomer), light-cured (light-activated glass ionomer analogue), and chemically-cured (conventional glass ionomer) materials. Changes in dimension, weight and flexural strength were examined from immediately after setting to the end of one week following immersion in water. The results obtained from these three types of material differed from each other, and showed a statistically significant correlation between changes in dimension and weight. This may be attributed to hygroscopic expansion. They also showed different flexural strength, indicating differences in the polymerization system. From these results, it appeared that marginal gaps following setting would be compensated for by hygroscopic expansion during immersion in water for one day or more. Physical properties would be favourably improved following the setting process which continues to advance during immersion in water.
\end{abstract}

Key words : Cavity liner, Hygroscopic expansion, Flexure strength

\section{INTRODUCTION}

With the growing use of the "sandwich technique", many base/liners having properties comparable to restorative materials have become available ${ }^{1-4)}$. These materials can be roughly divided into three groups. The first is conventional, made from a chemically-cured glass ionomer. This material has characteristics similar to conventional glass ionomers, such as (1) mildness to the pulp, (2) fluoride release, and (3) the ability to bond to dentin. The second is dual-cured, made from a light-activated glass ionomer. This is easier to manipulate while having characteristics similar to a chemically-cured glass ionomer. The third is light-cured, made from a light-activated glass ionomer analogue. It releases fluoride and is easy to manipulate.

Clinicians often complete a restorative procedure at one appointment, with little consideration about the type of base/liner material or potential damage to the pulp ${ }^{5-7)}$. In this respect, some reports state that early large gaps and the consequent exposition of freshly cut dentin could cause bacterial penetration and pulpal damage ${ }^{8,9)}$. Other state that restoration failure may occur in the earliest stage of the restoration ${ }^{10)}$.

Because the lining or base is one of the restorative procedures, we evaluated this on the same basis as a restorative material, and according to the effect of setting shrinkage on the marginal gap ${ }^{2,11}$. Hygroscopic expansion of restorative materials following immersion in water may be useful to compensate for marginal gap in cases of either composite resin ${ }^{9,12,13)}$ or chemically-cured glass ionomer ${ }^{14)}$. Because the matrix of hardened chemically-cured 
glass ionomer forms a polymer complex ${ }^{6,15,16)}$, we have considered that hygroscopic expansion might improve marginal seal ${ }^{17}$. Moreover, we would expect an increase in strength because the setting process advances during immersion in water. A flexural test was used to assess the strength to the base/liner materials ${ }^{18-21)}$.

In this study, we examined changes in the dimension, weight and the flexural strength of three base/liner materials, from immediately after setting to the end of one week following immersion in water, to characterize the initial stage of setting. A more effective way of handling base/liner materials in restorative procedures was also discussed.

\section{MATERIALS AND METHODS}

Two dual-cured, one light-cured, and two chemically-cured base/liner materials were used in this study (Table 1). Mixing was done according to the manufacturer's instructions. The light-activated material was exposed to a visible light source*. To determine the changes in dimension and weight, specimen sized $3.5 \mathrm{~mm}$ in diameter and $2 \mathrm{~mm}$ in height were prepared. In the case of dual-cured glass ionomer and light-cured base/liner material, they were cured for $30 \mathrm{~s}$. Chemically-cured glass ionomers were stored at $37^{\circ} \mathrm{C}$ and $100 \% \mathrm{R}$. H. for four min after mixing. Dimension and weight were measured immediately after lightactivation, $30 \mathrm{~min}, 24 \mathrm{~h}$ and one week following immersion in distilled water at $37^{\circ} \mathrm{C}$. The height of each cylindrical specimen was measured with an electric micrometer** and the change in the specimen's dimensions during storage was observed ${ }^{22}$. Water sorption was examined by a balancer\# and the change in the specimen's weight during storage was observed $^{22)}$. A specimen size of $15 \times 4 \times 2.5(\mathrm{~mm})$ was used for the determination of flexural

Table 1 Materials used

\begin{tabular}{|c|c|c|}
\hline Product & Batch No. & $\mathrm{P} / \mathrm{L}$ ratio \\
\hline \multicolumn{3}{|c|}{ Dual-cured (Light-activated glass ionomer) } \\
\hline Vitrebond $^{1}$ & P890426 & $1.4 \mathrm{~g} / 1.0 \mathrm{~g}$ \\
\hline Fuji Lining $\mathrm{LC}^{2}$ & 250803 & $1.4 \mathrm{~g} / 1.0 \mathrm{~g}$ \\
\hline \multicolumn{3}{|c|}{ Light-cured (Light-activated glass ionomer analogue) } \\
\hline Ionosit $^{3}$ & 81187 & \\
\hline \multicolumn{3}{|c|}{ Chemically-cured (Conventional glass ionomer) } \\
\hline Dentin Cement (for base) ${ }^{4}$ & 270401 & $2.2 \mathrm{~g} / 1.0 \mathrm{~g}$ \\
\hline Lining Cement (for lining) ${ }^{5}$ & 260111 & $1.2 \mathrm{~g} / 1.0 \mathrm{~g}$ \\
\hline 1 3M, St. Paul, USA & & \\
\hline 2 GC, Tokyo, Japan & & \\
\hline 3 DMG, Hamburg, Germany & & \\
\hline 4 GC, Tokyo, Japan & & \\
\hline 5 GC, Tokyo, Japan & & \\
\hline
\end{tabular}

* Luxor, Model 4000, ICI, Cheshire, England

* * Digimicro MU-1001B, Nikon, Tokyo, Japan

\# Balancer AJ100, Mettler, Greifensee, Switzerland 
strength. Dual-cured glass ionomer and light-cured base/liner materials were cured again in three overlapping sections. Each section was cured for 30 seconds. Chemically-cured glass ionomers were stored at $37^{\circ} \mathrm{C}$ and $100 \% \mathrm{R}$. H. for four minutes after mixing. Measurements were done using the 3 -point bending method with a $10 \mathrm{~mm}$-span and a loading speed of $0.5 \mathrm{~mm} / \mathrm{min}^{\# \#}$ at $23 \pm 2^{\circ} \mathrm{C}$ and $50 \pm 10 \% \mathrm{R}$. H..

Except for the strength measurements, all of the procedures were conducted in an airconditioned room, $22 \pm 0.5^{\circ} \mathrm{C}$ and $50 \pm 2 \%$ R. H.. Results were analyzed statistically by ANOVA and Duncan's Multiple-Range Test $(\mathrm{p}<0.01)$.

\section{RESULTS}

Tables 2 to 5 show the changes in dimension, weight and flexural strength.

The dual-cured type of material showed significant increases in dimension, weight and flexural strength up to $24 \mathrm{~h}$, and it was notably affected by water. Changes in the dimension and weight of the light-cured material were similar to that the dual-cured type, but the flexural strength was different. After one day of immersion, the light-cured type had greater flexural strength than the others. Flexural strength significantly declined, $-22 \%$, after one week. The chemically-cured type of material did not show any significant changes in dimension or weight, but there was a significant change in flexural strength. Flexural strength increased significantly after one day, although it was lower than that for the other materials.

Fig. 1 shows the relationship between the changes in dimension and weight. All of the types showed significant correlation.

Table 2 Dimensional change following immersion in water

\begin{tabular}{lcccc}
\hline \multicolumn{1}{c}{ Product } & \multicolumn{4}{c}{ Mean \pm S. D. (\%)* } \\
\cline { 2 - 4 } & $\begin{array}{l}\text { immediately } \\
\text { after setting }\end{array}$ & 30 minutes & 24 hours & 1 week \\
\hline Vitrebond & 0 & $2.4 \pm 0.2$ & $3.4 \pm 0.2$ & $3.4 \pm 0.4$ \\
Fuji Lining LC & 0 & $2.9 \pm 0.5$ & $6.2 \pm 0.6$ & $6.3 \pm 0.6$ \\
Ionosit & 0 & $0.2 \pm 0.1$ & $1.1 \pm 0.4$ & $2.4 \pm 0.4$ \\
Dentin Cement & 0 & $2.1 \pm 0.8$ & $2.3 \pm 0.9$ & $2.3 \pm 1.0$ \\
\cline { 2 - 4 } Lining Cement & 0 & $1.1 \pm 0.3$ & $1.1 \pm 0.4$ & $0.9 \pm 0.5$ \\
\hline
\end{tabular}

* The values represent the percent relative to that immediately after setting.

Values joined by vertical or horizontal lines were not significantly different $(\mathrm{p}<0.01, \mathrm{n}=10)$. 
Table 3 Weight change following immersion in water

\begin{tabular}{|c|c|c|c|c|}
\hline \multirow[t]{2}{*}{ Product } & \multicolumn{4}{|c|}{ Mean \pm S. D. (\%)* } \\
\hline & $\begin{array}{l}\text { immediately } \\
\text { after setting }\end{array}$ & 30 minutes & 24 hours & 1 week \\
\hline Vitrebond & 0 & $3.1 \pm 0.2$ & $7.3 \pm 0.2$ & $6.8 \pm 0.4$ \\
\hline Fuji Lining LC & 0 & $4.4 \pm 0.6$ & $9.9 \pm 0.6$ & $10.5 \pm 0.7$ \\
\hline Ionosit & 0 & $0.2 \pm 0.1$ & $1.4 \pm 0.4$ & $3.3 \pm 0.4$ \\
\hline Dentin Cement & 0 & $3.0 \pm 1.0$ & $4.2 \pm 0.7$ & $4.8 \pm 0.7$ \\
\hline Lining Cement & 0 & $3.1 \pm 0.3$ & $2.6 \pm 0.4$ & $2.3 \pm 0.5$ \\
\hline
\end{tabular}

* The values represent the percent relative to immediately after setting.

Values joined by vertical or horizontal lines were not significantly different $(\mathrm{p}<0.01, \mathrm{n}=10)$.

Table 4 Change in flexural strength following immersion in water

\begin{tabular}{|c|c|c|c|c|}
\hline \multirow[t]{2}{*}{ Product } & \multicolumn{4}{|c|}{ Mean \pm S. D. $(\mathrm{MPa})$} \\
\hline & $\begin{array}{l}\text { immediately } \\
\text { after setting }\end{array}$ & 30 minutes & 24 hours & 1 week \\
\hline Vitrebond & $14.6 \pm 1.1$ & $22.4 \pm 2.3$ & $38.7 \pm 2.3$ & $36.4 \pm 2.1$ \\
\hline Fuji Lining LC & $25.2 \pm 2.1$ & $33.3 \pm 4.4$ & $47.6 \pm 7.2$ & $58.6 \pm 3.9$ \\
\hline Ionosit & $60.6 \pm 6.0$ & $81.1 \pm 8.7$ & $85.4 \pm 7.1$ & $47.0 \pm 4.1$ \\
\hline Dentin Cement & $3.2 \pm 0.7$ & $6.1 \pm 1.0$ & $33.4 \pm 2.8$ & $26.7 \pm 3.1$ \\
\hline Lining Cement & $2.0 \pm 0.5$ & $3.8 \pm 0.7$ & $16.6 \pm 5.0$ & $18.2 \pm 4.2$ \\
\hline
\end{tabular}

Values joined by vertical or horizontal lines were not significantly different $(\mathrm{p}<0.01, \mathrm{n}=10)$.

Table 5 Comparison of change in flexural strengths following immersion in water

\begin{tabular}{lcccc}
\hline \multicolumn{1}{c}{ Product } & \multicolumn{4}{c}{ Mean (\%)* } \\
\cline { 2 - 5 } & $\begin{array}{c}\text { immediately } \\
\text { after setting }\end{array}$ & 30 minutes & 24 hours & 1 week \\
\hline Vitrebond & 0 & 53 & 165 & 149 \\
Fuji Lining LC & 0 & 32 & 89 & 133 \\
Ionosit & 0 & 34 & 41 & -22 \\
Dentin Cement & 0 & 91 & 944 & 734 \\
Lining Cement & 0 & 90 & 730 & 810 \\
\hline
\end{tabular}

* The values represent the percent relative to that immediately after setting. 


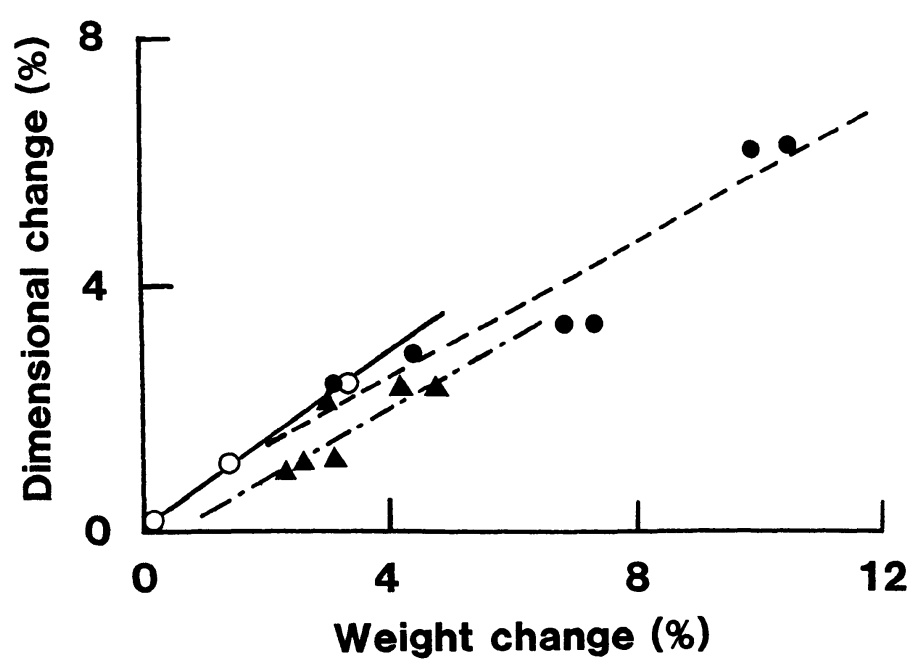

Fig. 1 Relationship between dimension and weight change of three base/liner materials.

Dual-cured type $(\mathrm{r}=0.94, \mathrm{p}<0.05)$

$\bigcirc-\bigcirc$ Light-cured type $(r=0.99, \mathrm{p}<0.05)$

$\Delta---\boldsymbol{\Delta}$ Chemically-cured type $(\mathrm{r}=0.83, \mathrm{p}<0.05)$

\section{DISCUSSION}

The three different type base/liner materials showed dissimilar changes in dimension, weight and flexural strength following immersion in water. This may be attributed to differences in composition, the polymerization system and the rate of hygroscopic expansion.

The dual-cured base/liner material is generally called a light-activated glass ionomer. Unlike chemically-cured glass ionomer, it has a dual setting reaction consisting of an acid -base reaction and a photochemical polymerization process ${ }^{15,23,24}$. In Vitrebond, the polymeric structure includes both poly (HEMA) and graft coplymers of HEMA as well as carboxylic acid and carboxylates arising from the modified poly (acrylic acid) component ${ }^{23}$. The hardened Fuji Lining LC is composed of a matrix of uniformed polyacrylic metal salt and Poly (HEMA) around powder particles ${ }^{24)}$. Because of its hydrophilic nature, HEMA expands when it is immersed in water. This explains why its water absorption, changes in dimension, and hydroscopic expansion is greater than that of chemically-cured glass ionomer ${ }^{23)}$. While the dimensions of the chemically-cured type did not change after $30 \mathrm{~min}$ of immersion, dual-cured type showed changes up to $24 \mathrm{~h}$. This can also be explained by the matrix containing Poly-HEMA. The water absorption rate obtained in our study was different from the results of Nicholson and his colleagues ${ }^{23)}$. This may be due to differences in the baseline. Nicholson and his colleagues set the baseline at $1 \mathrm{~h}$ of storage of the materials in an atmosphere at $37^{\circ} \mathrm{C}$, while our baseline was immediately after exposure to the light. Although Vitrebond and Fuji Lining LC showed similar changes following water immersion, Fuji Lining LC provided significantly higher water absorption. Forss ${ }^{25}$ obtained 
similar results. This is probably due to differences in the structure of the included hardened materials and the percentage of incorporated $\mathrm{HEMA}^{23,25)}$.

The same explanation can be applied to the flexural strength of the dual-cured type. The matrix formed is more complex because it contains Poly-HEMA, chemically linked to the polyacrylate matrix ${ }^{26)}$ and powder particles are pretreated with silane ${ }^{24)}$. Because of this structure, the dual-cured type exhibited significantly higher flexural strength than the chemically-cured type, as in compressive strength ${ }^{4}$. Vitrebond and Fuji Lining LC showed similar changes in flexural strength following immersion in water, although the latter was significantly higher. Changes in flexural strength were consistent with Lewis's report ${ }^{4)}$.

The composition described by the manufacturer implies that the major organic components of the light cured type (Ionosit) are hydrophobic Bis-GMA and TEGDMA. This probably accounts for the difference in properties after immersion in water between light -cured and dual-cured types of base/liner. The light-cured type contains silica filler up to $66 \%$, comparable to that of restorative composite. This may explain the fact that the light -cured type exhibited significantly higher flexural strength than the dual-cured type following $24 \mathrm{~h}$ immersion in water (e. g., flexural strength of Silux Plus (3M) after $24 \mathrm{~h}$ immersion : $75.4 \pm 8.5 \mathrm{MPa}, \mathrm{n}=10)^{17)}$. When this material was immersed in water for 1 week, the value for flexural strength was significantly lower than the value obtained following $24 \mathrm{~h}$ immersion in water. This is probably due to the low durability in water. Although the light-cured type has been used as a base/liner for composite restoration, the sealability was not as good as that of the dual-cured type ${ }^{6}$. The lower hygroscopic expansion rate of the light-cured type may have caused such poor results.

A chemically-cured type (Dentin Cement) showed significantly higher hygroscopic expansion and flexural strength than others (Lining Cement). Because of their different powder-liquid ratio, the difference in the microstructure was reflected in the two cements $^{27,28)}$. When this material (Dentin Cement) was immersed in water for 1 week, the flexural strength was significantly lower than it was following $24 \mathrm{~h}$ immersion in water. This is probably due to the low durability in water.

When comparing the setting shrinkage rate of the three base/liner materials ${ }^{11}$, the specimens used in this study were made with teflon molds of the same size. Table 6 showed that the three base/liner materials were shrunk by light-activation or during the initial

Table 6 Change in dimension following filling

\begin{tabular}{lclccc}
\hline \multicolumn{1}{c}{ Product } & \multicolumn{5}{c}{ Mean (\%)* } \\
\cline { 2 - 5 } & $\begin{array}{l}\text { immediately } \\
\text { after } \\
\text { filling }\end{array}$ & $\begin{array}{l}\text { immediately } \\
\text { after } \\
\text { setting }\end{array}$ & 30 minutes & 24 hours & 1 week \\
& 0 & -1.4 & 0.9 & 1.9 & 1.9 \\
Vitrebond & 0 & -0.7 & 2.2 & 5.5 & 5.6 \\
Fuji Lining LC & 0 & -0.3 & -0.1 & 0.8 & 2.1 \\
Ionosit & 0 & -0.6 & 1.5 & 1.7 & 1.7 \\
Dentin Cement & 0 & -1.1 & \pm 0 & \pm 0 & -0.2 \\
Lining Cement & 0 & & & \\
\hline
\end{tabular}

* The values represent the percent relative to that immediately after filling. 
setting in the first stage ${ }^{11}$, and then they were expanded by water sorption as suggested by the results of this study. That is, the setting shrinkage rate was theoretically compensated for by the hygroscopic expansion rate following immersion in water for $24 \mathrm{~h}$. In addition, hygroscopic expansion would release stress generated during the setting process ${ }^{29}$.

Therefore, even though a dual-cured base/liner material can be used clinically, it is not recommended to complete the restoration at one appointment. As Fujii advocated ${ }^{30)}$, we also recommend filling the cavity temporarily with a base/liner material at the first appointment, and then completing the remaining restorative procedures at the following appointment. This should improve the marginal gap in the tooth cavity and the strength of material during immersion in water for one or more days, as suggested by the results of this study. It is not good practice to restore in the early stage as marginal gaps may occur in the tooth cavity $^{17)}$ and distortion of the material may occur in the early setting stage ${ }^{29)}$. Some studies $^{8,9)}$ have stated that large gaps and the exposure of freshly cut dentin would cause bacterial penetration and pulpal damage.

\section{CONCLUSION}

Three base/liner materials having different polymerization systems were tested, and showed different changes in dimension, weight and flexural strength following immersion in water. Some of these changes may be used effectively to eliminate marginal gaps during the early stage of setting. It is recommended to fill the prepared cavity temporarily with a base/liner material at the first appointment and, to perform the remaining restorative procedures at the following appointment.

\section{ACKNOWLEDGMENTS}

This study was supported by a Grant-in-Aid for General Scientific Research No. 04671184 from the Ministry of Education, Science and Culture of Japan, as well as by a Grant-in-Aid for Scientific Research from the Ryobi Teien Memorial Foundation (Okayama).

\section{REFERENCES}

1) Tam, L. E., Pulver, E., McComb, D. and Smith, D. C.: Physical properties of calcium hydroxide and glass-ionomer base and lining materials, Dent Mater 5 (3) : 145-149, 1989.

2) Irie, M., Tanaka, J., Nakai, H., Hirota, K. and Tomioka, K.: The marginal gap and bond strength of glass ionomers for base/liner, J Dent Res 69 : 311 (Abstr. No. 1620), 1990.

3) Hörsted -Bindslev, P. and Larsen, M. J. : Release of fluoride from light cured lining materials, Scand $J$ Dent Res 99 (1): 86-88, 1991.

4) Lewis, B. A., Burgess, J. O. and Gray, S. E. : Mechanical properties of dental base materials, $A m J$ Dent 5 (2): 69-72, 1992.

5) Sheth, J. J., Jensen, M. E., Sheth, P. J. and Versteeg, J. : Effect of etching glass-ionomer cements on bond strength to composite resin, J Dent Res 68 (6) : 1082-1087, 1989.

6) Bergmann, P., Blunck, U., Roulet, J. -F. and Noack, M. J. : Marginal behaviour of composite restorations with expanding bases in vitro, $J$ Dent Res 68: 979 (Abstr. No. 900), 1989.

7) Suzuki, M. and Jordan, R. E. : Glass ionomer-composite sandwich technique, J Am Dent Assoc 120 (1) : 55-57, 1990 . 
8) Brännström, M., Torstenson, B. and Nordenvall, K. -J.: The initial gap around large composite restorations in vitro: The effect of etchig enamel walls, $J$ Dent Res 63 (5) : 681-684, 1984.

9) Torstenson, B. and Brännström, M. : Contraction gap under composite resin restorations : Effect of hygroscopic expansion and thermal stress, Oper Dent 13 (1) : 24-31, 1988.

10) Prati C: Early marginal microleakage in Class II resin composite restorations, Dent Mater 5 (6) : 392 $-398,1989$.

11) Irie, M. and Nakai, H. : Marginal gap formation of light-activated base/liners : Effect of shear bond strength and setting shrinkage, Dent Mater (Accepted).

12) Asmussen, E. and J $\phi$ rgensen, K. D. : A microscopic investigation of the adaptation of some plastic filling materials to dental cavity walls, Acta Odontal Scand 30 (1) : 3-21, 1972.

13) Hansen, E. K. and Asmussen, E. : Marginal adaptation of posterior resins : Effect of dentin-bonding agent and hygroscopic expansion, Dent Mater 5 (2) : 122-126, 1990.

14) Irie, M, and Nakai, H.: The marginal gap and bonding strength of glass ionomers, Dent Mater J 6 : 46-53, 1987.

15) Mitra, S. B. : Adhesion to dentin and physical properties of a light-cured glass-ionomer liner/base, $J$ Dent Res 70 (1) : 72-74, 1991.

16) Bourke, A. M., Walls, A. W. and McCabe, J. F.: Light-activated glass polyalkenoate (ionomer) cements: The setting reaction, J Dent 20 (2): 115-120, 1992.

17) Irie, M. and Nakai, H. : Marginal gap of light-activated glass-ionomers: Effect of hygroscopic expansion, J Dent Res 71: 633 (Abstr. No. 941), 1992.

18) Prosser, H. J., Powis, D. R. and Wilson, A. D. : Glass-ionomer cements of improved flexural strength, $J$ Dent Res 65 (2): 146-148, 1986.

19) Tjan, A. H. L. and Morgan, D. L. : Metal-reinforced glass ionomers: Their flexural and bond strengths to tooth substrates, J Prosthet Dent 59 (2) : 137-141, 1988.

20) Irie, M. and Nakai, H.: Mechanical properties of silver-added glass ionomers and their bond strength to human tooth, Dent Mater J 7 (1): 87-93, 1988.

21) Pearson, G. J. and Atkinson, A. S. : Long-term flexural strength of glass ionomer cements, Biomater ials 12 : 658-660, 1991.

22) Irie, M. and Nakai, H.: Change in physical properties of tannin fluoride-containing luting cements following immersion in water up to 12 months, Dent Mater J 3 (2) : 205-209, 1984.

23) Nicholson, J. W., Anstice, H. M. and McLean, J. W.: A preliminary report on the effect of storage in water on the properties of commercial light-cured glass-ionomer cements. Brit Dent J 173 (3) : 98-101, 1992.

24) Tosaki, S. and Hirota, K. : Current and future trends for light cured systems, In: Hunt, P. R., editor. Glass ionomers. The next generation. Proceedings of the 2nd international symposium on glass ionomers, June 16-19, 35-46, 1994.

25) Forss, H. : Release of fluoride and other elements from light-cured glass ionomers in neutral and acidic conditions, J Dent Res 72 (8): 1257-1262, 1993.

26) Wilson, A. D. : Resin-modified glass-ionomer cements, Int J Prosthodont 3 (5) : 425-429, 1990.

27) Hatton, P. V. and Brook, I. M.: Characterization of the ultrastructure of glass-ionomer (poly -alkenoate) cement, Brit Dent J 173 (8) : 275-277, 1992.

28) Wasson, E. A. and Nicholson, J. W. : New aspects of the setting of glass-ionomer cements, $J$ Dent Res 72 (2) : 481-483, 1993.

29) Davidson, C. L., Leloup, G. and de Gee, A. J. : Self repair of damaged glass-ionomer cement, J Dent Res 73: 181 (Abstr. No. 634), 1994.

30) Fujii, B.: Restorative techniques: New concept, Dental Diamond Co., Tokyo, 1991, pp. 52-76. (in Japanese) 


\section{歯槽骨欠損部の CPC 填入後の組織学的治癒反応}

藤川謙次，菅原明喜 ${ }^{1}$, 村井正大, 西山 實 $^{1}$

高木章三 ${ }^{2}, \mathrm{CHOW}$, L. C. ${ }^{2}$

日本大学歯学部保存学教室歯周病学講座

${ }^{1}$ 日本大学歯学部歯科理工学教室

${ }^{2}$ Paffenbarger Reasearch Center, ADAHF, NIST

自然発生に類似した歯周疾患を惹起させた 3 壁性歯槽 骨欠損部に対してフラップ手術を行い， CPC あるいは $\mathrm{AP}$ を周囲歯槽骨頂縁部と同じ高さになるまで填入し た. 術後一定期間経過した後の組織学的変化を調べた結 果, 術後 1 力月では, $\mathrm{CPC}, \mathrm{AP}$ ともに隣接組織に炎症反 応は認められなかった. 術後 3 カ月目に一部新生骨の添 加はみられたが, AP の全周は密な線維性結合組織で覆 われていた。一方, CPC 填入部位は歯槽骨に接している 付近あるいは歯冠側結合組織付近から部分的に新生骨に
置換していた. 術後 6 カ月目には, CPC 填入部位はほと んど新生骨によって置換されていたが, AP は 3 カ月目 と同様の所見を示した. CPC を歯槽骨補填に応用した場 合, 術後 3 力月目には CPC の表層および歯槽骨欠損部 の周囲骨面からの骨の形成が認められた，現在このよう な特性を示す材料が他にみられないことより，本材料が 臨床における未解決の分野に応用し得る可能性があるも のと判断された。

\section{酸を用いない象牙質面処理 \\ 谷 嘉明，都賀谷紀宏 \\ 京都大学生体医療工学研究センター}

従来から, 象牙質面の処理には, その酸性度の高低, 有機・無機に差はあるものの主として酸が用いられてき た。しかし, 歯髄保護の観点から, 処理液は酸でないほ うが望ましい。そこで促来全く着目されていなかった無 機物の水溶液による酸を用いない象牙質面処理を試み た。前処理剤として用いたのは, チオシアン酸カリウム (KSCN)（ロダンカリ）の水溶液で，ロダン化物水溶液 のもつコラーダンおよびその変成物（や゙ラチン）の膨潤
を促進する salting in 効果に着目し, smear layer が良 好に除去されることをあきらかにした，また上記の溶液 に架橋剤として三価の金属塩（塩化第 2 鉄，鉄ミョウバ ン，カリウムミョウバン）を添加した処理液を用いて処 理した結果，処理面は smearlayer が良好に除去され， dentinal plugs は閉塞されている所見が観察された.さ らに，低濃度のロダンカリ水溶液でも scrubbing するこ とによって良好に処理されることが分かった。

\section{浸水による裏層材の線膨張と強さの変化}

入江正郎，中井宏之

岡山大学歯学部歯科理工学講座

硬化方式の異なる 3 種の裏層材（デュアルキュアー型 すなわち光硬化型グラスアイオノマー, 光重合型すなわ ち光硬化型グラスアイオノマー類似物, 化学重合型すな わち従来型グラスアイオノマー) の硬化初期の特性を把
握するため, 硬化直後から水中浸漬 1 週間後までの寸法, 重量および曲げ強さの変化を測定した。3 種の裏層材は それぞれ異なった変化を示した。水中浸漬 1 週間までの 寸法と重量変化とは 3 種共に有意な関係にあった.これ 
は吸水膨張によると想像された。曲げ強さはそれぞれ異 なり, 硬化方式の違いを示す強さの経時的変化がみられ た。この結果から，1 日以上水中浸漬されることによる
昅水膨張によって, 裏層材の硬化時に生じる窩洞辺縁部 との間隙を防止したり，硬化が進行することによる物性 の安定化が期待された。

\section{コンポジットレジンの機械的性質の低下 \\ 有川裕之, 桑畑弘之, 関 英男, 蟹江隆人 藤井孝一，井上勝一郎 \\ 鹿児島大学歯学部歯科理工学講座}

$\gamma$-MPTMS によって表面処理した 6 種類のフィラー を用い，異なったフィラー形状，フィラー粒径，フィラ 一含有率をもつ 16 種類の光重合型コンポジットレジン を試作した。試料は $0 \sim 60$ 日間蒸留水中に浸漬し, 曲げ 強さおよび曲げによる応力緩和率の測定を行った。曲げ 強さは, すべての材料で水中浸漬期間が長くなるととも に隇少し，60日後では浸清前に比べて約 10〜30％低下 した。またフィラー含有率の高い材料 (65 vol \%) は含有
率の低い材料 $(40 \mathrm{vol} \%$ ）よりも大きな低下率を示した。 応力緩和率についても曲げ強さの場合と同様の傾向を示 し, 浸漬期間が長くなるにつれて緩和率は増加した。さ らにフィラー含有率の高い材料は, 浸漬前の値に比べて より大きな緩和率の増加を示す傾向がみられた。こうし た機械的性質の低下は, フィラー表面処理剤の加水分解 による劣化が大きな影響を及济しているものと思われ る。

\section{硬質せっこうの脱水過程に生ずる比熱測定における異常ピーク \\ 久恒邦博，A. El-Araby，岩沼健児，田中康弘 有働公一，安田克廣 \\ 長崎大学歯学部歯科理工学講座}

断熱型比熱測定装置により，硬質せっこう硬化体の脱 水過程を検討した。一般には大気中において，二水塩か ら半水塩を経由して無水塩への二段階の脱水過程を示す ことが知られている。しかし，混水比の小さいバルク試
料の脱水は見かけ上，三段階で進行する。これは本質的 なことでなく，ち密な硬化体が円滑な脱水をさまたげる ことにより生じたピークであると考えられる。 